\title{
FINANCIAL INCLUSION - ONE STEP CLOSER TO THE EUROZONE?
}

\author{
Oana Mirela Cojocaru (Diaconescu), Otilia Georgiana Floroiu * \\ Doctoral School of Social Sciences, Stefan cel Mare University of Suceava, Romania \\ diaconescu oana@yahoo.com \\ otilia.floroiu@yahoo.com
}

\begin{abstract}
Factors leading to financial exclusion are primary linked to shortages of financial resources, high costs for financial services, distrust in financial institutions, and lack of financial education. Financial inclusion of the population can sustain economic monetary and financial stability by taking efficient saving and investing decisions or by boosting the performance of an economy. In a responsible financial system, people can safely save money without fearing losing it as a result of fraud, theft, or operational errors, can conduct financial transactions, can take a loan for consumption or for investing in personal development or business idea with a proper understanding of the terms and conditions, and they can insure themselves against any kind of risk. Considering that financial exclusion leads to social exclusion, the need to establish institutions that can offer marginalized categories of the population access to different financing means is obvious, especially in rural areas. People can use financing for self-employment or for implementing entrepreneurial ideas that can generate new jobs and revenue for the community. This paper adds to the existing literature in identifying the existing relations between financial inclusion and economic growth and further investigates if an increase in the level of financial inclusion has an impact on achieving the convergence criteria and therefore entering the Eurozone.
\end{abstract}

Keywords: financial inclusion, financial literacy, Eurozone, Euro currency, economic growth.

JEL classification: O11, G00, G22, I22, O15, R58.

\section{Introduction}

A topical issue is represented by the financial exclusion as a considerable percentage of the world's population does not have basic knowledge or any access to financial or banking services. In this paper, we are interested in emphasizing the primordial role that financial inclusion plays in economic growth, especially in developing countries and Romania.

Romania is currently struggling to achieve the convergence criteria for entering the Eurozone and recent research shows that by developing the financial services, better convergence results could be achieved.

Romania joined the European Union in 2007 and the euro adoption is an obligation enforced by the EU Accession Treaty. Currently the Eurozone consists of 19 countries: Belgium, Germany, Finland, France, Ireland, Italy, Luxembourg, Netherlands, Austria, Portugal, Spain, Greece, Slovenia, Cyprus, Malta, Slovakia, Estonia, Latvia and Lithuania. There are 9 countries: Bulgaria, Croatia, Denmark, Czech Republic, Denmark, Hungary, Poland, Romania, Sweden and the United Kingdom that are EU members but do not use the euro as a currency. Denmark and the United Kingdom are legally exempt from joining the Eurozone through special opt-outs obtained through the original Maastricht Treaty.

\footnotetext{
* Corresponding author: Otilia Floroiu
} 
Romania is required by the accession agreement to replace the national currency, the Romanian RON with the Euro, as soon as it fulfills the nominal euro convergence and the appropriate levels of real convergence criteria.

The convergence criteria refer to price stability, sound public finances, exchange rate stability and durability convergence. Based on the last convergence report (Convergence Report 2018), Romania is currently the least prepared EU Member state for adopting the euro by meeting only one out of four criteria, the one related to sound public finances.

Bulgaria currently fulfills three out of the four conditions, the Czech Republic two out of four, Croatia three out of four, Hungary two out of four, Poland two out of four and Sweden three out of four economic criteria.

Financial inclusion requires homogeneous availability and usage of financial services. Especially in developing countries, access to credit facilitates and encourages financial development and economic outcomes.

\section{Literature overview}

Financial stability contributes to the sustainable development of the countries and ensures efficiency of resources and financial intermediation. As a result, policymakers worldwide are interested in understanding and preventing financial exclusion.

There are three levels of financial inclusion (Allen et al., 2012): ownership of a formal bank account, use of a formal savings account and frequent use of the account consisting of three or more withdrawals every month.

The ownership of a formal bank account is considered a first step to many types of economic and social inclusion (Dermiguc and Klapper, 2013) for multiple reasons: it is often necessary to get a salary or public subsidies, it allows for more liquidity and gives access to savings, it reduces transaction costs, it is useful when accessing a credit, it strengthens the financial autonomy for women, it helps smoothen consumption and investments and it reduces the risk of fraud. The researchers show that the importance of informal financial inclusion in the developing countries is not only emphasized by sight accounts but also by savings and loans.

Developed and inclusive financial system presents the potential to reduce information and transaction costs (Beck et al., 2007), impact saving rates, investment decisions, technological innovation and the long-run growth rates. The development of financial inclusion does not only depend on the health of the financial markets, but also on the entire ecosystem defined through economic, political, social and the technological fields.

Financial inclusion has therefore received a great deal of attention from researchers, politicians, and other financial stakeholders. It is broadly believed that because people with low incomes are being refused the right to access financial services, the risk of social exclusion is aggravated. Compared to the Euro Zone members, Romania is presented with the highest values of poverty or social exclusion risks. Similarly, studies conducted further in this paper show that the financial exclusion levels reach the highest values for the EU in Romania. 


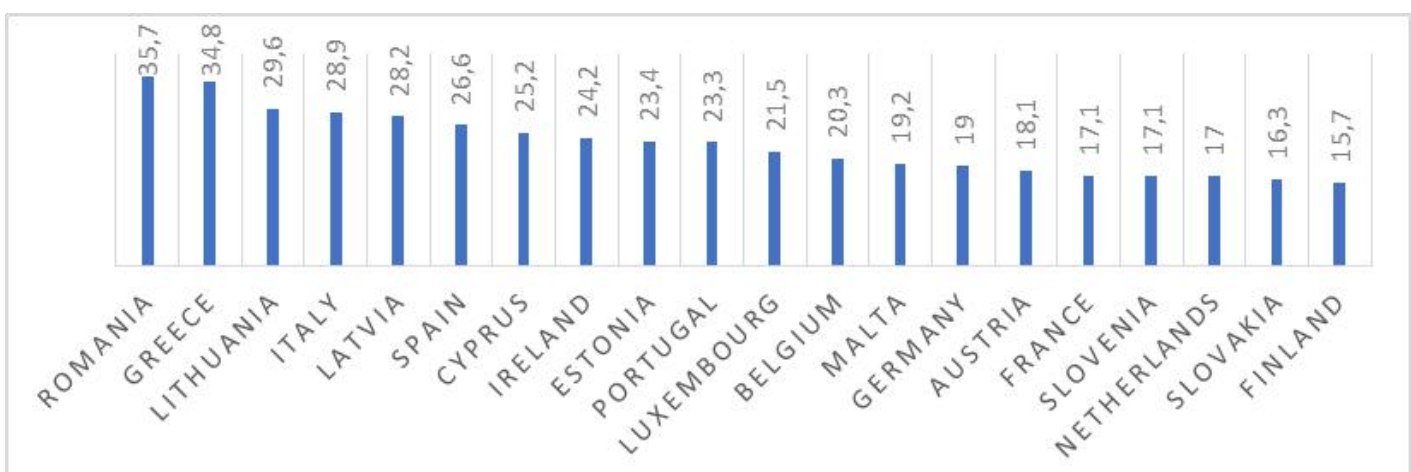

Figure 1: People at risk of poverty or social exclusion by NUTS 2 regions in 2017 (\% of total population)

Source: Author's own computation based on Eurostat data

Post financial crisis literature has focused on how financial inclusion affects economic outcomes. It has been revealed (Kim et al., 2018) that there is a relationship between levels of financial exclusion and economic growth or poverty. The conclusion was reached after analyzing 55 Organizations of Islamic Cooperation countries by using a dynamic panel regression analysis.

Similar studies (Chauvet and Jacolin, 2017) showed that the impact of financial deepening on growth may depend on the degree of financial inclusion in developing and emerging countries, based on a sample of 55596 firms in 79 countries.

The relationship between one of the financial inclusion factors, insurance market penetration, and economic growth has been closely examined (Pradhan et al., 2016) and findings concluded that there is a bidirectional causality between the insurance market and economic growth. Another recent research based on transition economies of Central and Eastern European Union (Bayar and Gavriletea, 2018) revealed the existence of a one - way causality between financial markets access and economic growth. Other empirical research (Delis et al., 2013) shows that financial development decreases income inequality based on the type of policy implemented.

An analysis (Naceur and Samir, 2007) of the relationship between financial development and economic growth for a total of 11 countries from Middle East and North Africa region showed that undeveloped financial systems in the MENA region impede economic growth. As financial exclusion plays an important role, not only for social reasons, but also for economic purposes, further studies (Ampudia and Ehrmann, 2017) concluded that financial inclusion is highly correlated to national wealth.

\section{Financial inclusion - measuring and scores}

Financial inclusion of the poor must be closely considered as it represents a way through which people have access to different types of funding that can help them overcome poverty. This point of view is also shared by the European Commission who claims that financial exclusion is closely linked to social exclusion.

Many countries regard financial inclusion as a part of the economic and social development process. For example, in 1997 the US adopted the Community Reinvestment Act through which banks were required to grant loans in low income areas. Similarly, France passed a law against exclusion emphasizing the right of their citizens to open a bank account and the UK founded a Financial Inclusion Task Force in 2005, to monitor the degree of financial inclusion. Furthermore, data is constantly being collected by the World Bank, the 
International Monetary Fund and the European Commission in order to develop policies for achieving financial inclusion.

The European Commission together with Microfinance Center treat financial inclusion as the financial system's ability to offer a wide range of products and services that are appropriate for all the individuals interested in using them.

An inclusive financial system operates as an open system in the sense that it allows anyone to use it (when and if needed) by offering the same terms and conditions. However, finding methods through which financial inclusion can be streamlined and supported through programs and policies is the real challenge.

One way to measure financial inclusion is by quantifying the level of financial literacy. An international study conducted in 2015 by Standard and Poor's and the World Bank reveals that $33 \%$ of adults (3.5 billion people) worldwide have basic financial knowledge. Although in Europe this percentage was as high as 52 , Romania ranked last when compared to other European countries with a percentage of only 22 . The situation is also similar worldwide as Romania ranked 123rd out of 143 countries included in the study. The researchers conducting the study emphasized that in poorer countries "national policies such as those linked to education and consumer protection are shaping the financial literacy of their economies more than any other factor of influence".

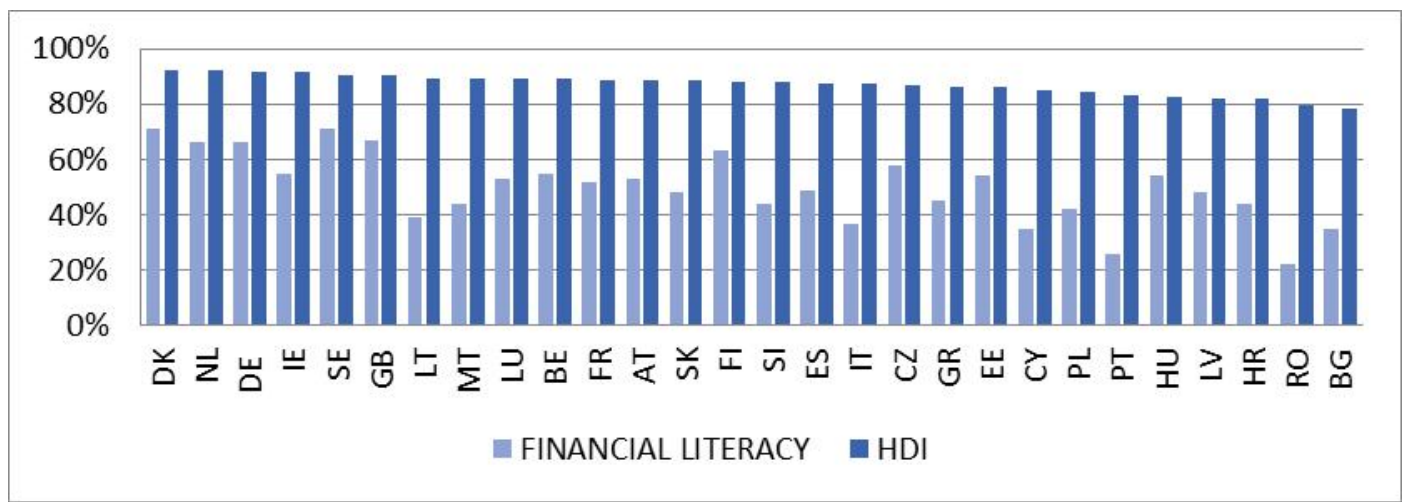

Figure 2: Financial literacy in the European Union in 2014 (\% total population)

Source: Klapper, Lusardi and van Oudheusden (2015)

It can be noticed that the financial literacy level is not correlated to the HDI (Human Development Index) value for European countries. There are countries with high HDI that have a level of financial literacy more reduced than countries with low HDI: Lithuania, Austria, Portugal, Italy and Spain. A level of $50 \%$ in financial literacy is recorded in Hungary, Estonia, Czech Republic and Austria. The highest values are reached by Denmark and Sweden $(71 \%)$ whereas the lowest values are recorded in Cyprus and Bulgaria with $35 \%$ and Romania with $22 \%$. Worldwide, in 2014 Norway scored the highest value $(71 \%)$ and Afghanistan the lowest (14\%).

Another method of quantifying the degree of financial exclusion is by dividing the population into banked people, unbanked people, and the marginalized group. Based on the study carried by Réseau Financement Alternatif between 2007 and 2008, the European Commission brings together evaluation reports for fourteen European countries (Romania not included) with the purpose of identifying measures that can be used in order to prevent financial exclusion among poor people or socially excluded individuals. It is believed that because of that fact that people with low incomes are being refused the right to access financial services, risk of social exclusion is aggravated. The levels of financial exclusion for the countries included in the analysis showed that $20 \%$ of adults don't have any access to financial services, approximately $30 \%$ don't have a savings account, and $40 \%$ do not have a 
credit line to their name (although only $10 \%$ had their applications rejected). In new member states, $33 \%$ of adults are financially excluded, over $50 \%$ do not have a bank account or a savings account, and over $75 \%$ don't have immediate access to permanent credit. The groups that are most likely to be financially excluded are people with low income, people living in rural areas, immigrants, and unemployed people. The fact that the countries that ranked last don't show a governmental concord towards financial exclusion is very troubling.

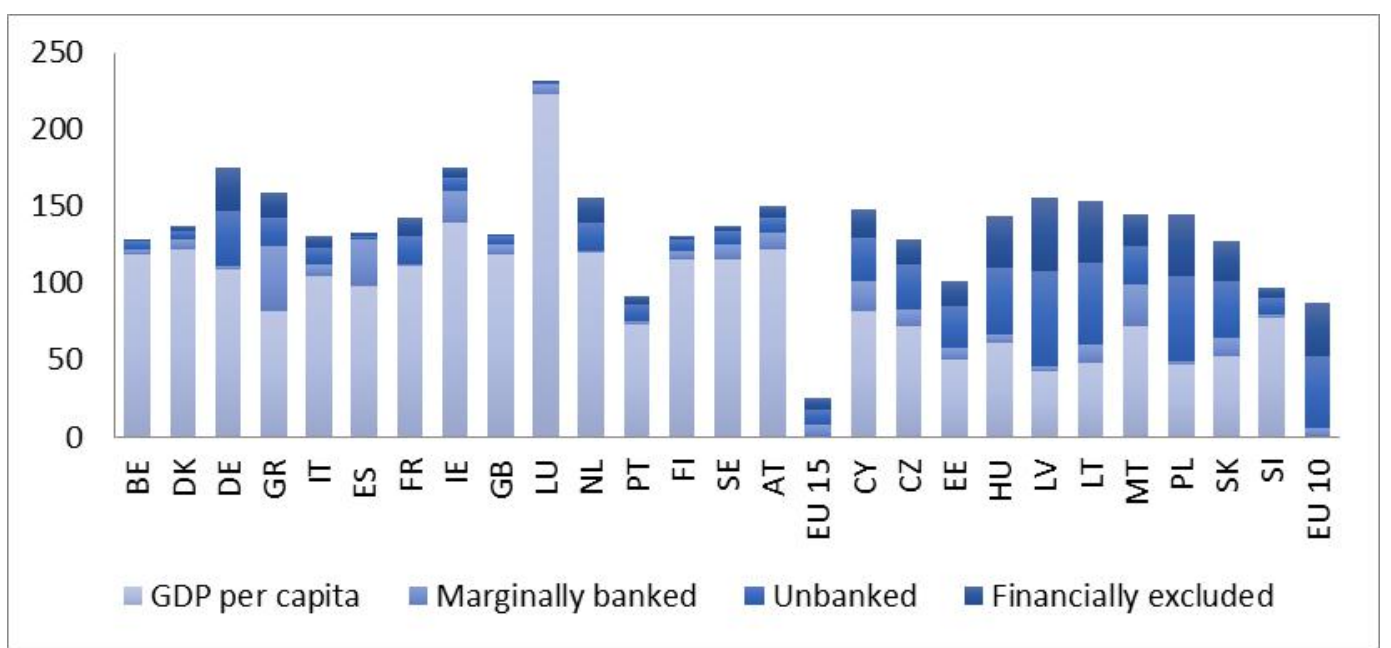

Figure 3: Level of financial exclusion among 15 European countries recorded between 2007-2008 (\% total adult population)

Source: European Commission (2008)

In countries such as Denmark, Belgium, Luxembourg, and the Netherlands, the recorded level of financial exclusion is $1 \%$ while at the opposite side of the spectrum Poland $(40 \%)$ and Lithuania $(48 \%)$ can be found.

The study reveals that the level of financial exclusion is negatively correlated with the GDP per capita. The percentage of unbanked and banked people, marginalized groups, and financially excluded individuals is higher in EU 10 than in EU 15 except for Slovenia.

The method used to quantify the degree of financial inclusion was based on a macro-level inclusion approach consisting of the calculation of a composite European Financial Inclusion Index (FII). This is a performance index based on relative measure and rating of the financial systems from each country by comparing them to the benchmark. The method used was the DEA (Data Envelopment Analysis) procedure for optimization.

The financial inclusion of a system can be represented as a set of outputs concerning the actual use of basic financial systems including current accounts, consumer credits, savings accounts, and insurance policies. The inputs include supply factors such as the financial services infrastructure, demand factors such as service quality of how well the consumer expectations are met and policies adopted to develop the financial inclusion in a country of choice.

A score of 1 for the financial inclusion index shows that the system is successfully converting the access factors involved and it automatically becomes a benchmark for the other countries. A value less than one for the FII shows that the financial system is less inclusive than the benchmark. In both cases $(F I I=1, F I I<1)$ it is still possible for some people to be excluded from using financial services and further measures need to be developed to highlight the specific nature and scale of the exclusion.

Table 1: Financial inclusion score and rankings for 27 EU Countries in 2011 


\begin{tabular}{|c|c|c|c|}
\hline Category & Country & Rank & FII \\
\hline \multirow[t]{11}{*}{ Leaders } & Sweden & 1 & 1.000 \\
\hline & Denmark & 2 & 1,000 \\
\hline & Finland & 3 & 1,000 \\
\hline & Ireland & 4 & 1.000 \\
\hline & France & 5 & 1.000 \\
\hline & Cyprus & 6 & 1.000 \\
\hline & Slovenia & 7 & 1.000 \\
\hline & Germany & 8 & 1.000 \\
\hline & Latvia & 9 & 1.000 \\
\hline & Spain & 10 & 1.000 \\
\hline & Netherlands & 11 & 1.000 \\
\hline \multirow[t]{8}{*}{ High performers } & Malta & 12 & 0.999 \\
\hline & Austria & 13 & 0.996 \\
\hline & Belgium & 14 & 0.987 \\
\hline & Estonia & 15 & 0.964 \\
\hline & UK & 16 & 0.962 \\
\hline & Slovakia & 17 & 0.930 \\
\hline & Czech Rep. & 18 & 0.921 \\
\hline & Luxemburg & 19 & 0.904 \\
\hline \multirow[t]{6}{*}{ Aspiring performers } & Portugal & 20 & 0.876 \\
\hline & Hungary & 21 & 0.841 \\
\hline & Greece & 22 & 0.840 \\
\hline & Italy & 23 & 0.800 \\
\hline & Lithuania & 24 & 0.753 \\
\hline & Poland & 25 & 0.747 \\
\hline \multirow[t]{2}{*}{ Laggards } & Bulgaria & 26 & 0.567 \\
\hline & Romania & 27 & 0.554 \\
\hline
\end{tabular}

Source: Korynski, Pytkowska (2014)

The data presented in the previous table shows that Romania ranked last in the financial inclusion hierarchy of European countries.

The inclusion index components analysis demonstrates that although in Romania access factors are efficiently applied (supply factors 6th place, public policy factors 4th place, demand factors 10th place) the outcome is still unsatisfactory as Romania ranked 27th.

Table 2: FIS score and FIS input rankings in 2011

\begin{tabular}{|l|c|c|c|c|}
\hline \multicolumn{1}{|c|}{ Country } & FIS rank & Supply & Policy & Demand \\
\hline Sweden & 1 & 1 & 1 & 1 \\
\hline Denmark & 2 & 4 & 2 & 2 \\
\hline Finland & 3 & 3 & 7 & 13 \\
\hline Ireland & 4 & 12 & 3 & 7 \\
\hline France & 5 & 19 & 8 & 3 \\
\hline Cyprus & 6 & 21 & 15 & 11 \\
\hline Slovenia & 7 & 22 & 20 & 8 \\
\hline Germany & 8 & 13 & 26 & 20 \\
\hline
\end{tabular}




\begin{tabular}{|l|c|c|c|c|}
\hline \multicolumn{1}{|c|}{ Country } & FIS rank & Supply & Policy & Demand \\
\hline Latvia & 9 & 16 & 23 & 26 \\
\hline Spain & 10 & 27 & 19 & 21 \\
\hline Netherlands & 11 & 15 & 27 & 27 \\
\hline Malta & 12 & 24 & 24 & 18 \\
\hline Austria & 13 & 7 & 6 & 5 \\
\hline Belgia & 14 & 17 & 16 & 6 \\
\hline Estonia & 15 & 20 & 25 & 25 \\
\hline UK & 16 & 18 & 17 & 16 \\
\hline Slovakia & 17 & 5 & 13 & 9 \\
\hline Czech Rep. & 18 & 2 & 9 & 19 \\
\hline Luxemburg & 19 & 14 & 5 & 4 \\
\hline Portugal & 20 & 26 & 21 & 22 \\
\hline Hungary & 21 & 8 & 14 & 23 \\
\hline Greece & 22 & 25 & 22 & 24 \\
\hline Italy & 23 & 23 & 12 & 17 \\
\hline Lithuania & 24 & 10 & 18 & 14 \\
\hline Poland & 25 & 9 & 10 & 12 \\
\hline Bulgaria & 26 & 11 & 11 & 15 \\
\hline Romania & 27 & 6 & 4 & 10 \\
\hline
\end{tabular}

Source: Korynski, Pytkowska (2014).

The Total Financial Inclusion Index (TFI) is another index used to easily measure the level of financial inclusion as the total percentage of adults using at least one financial product or service. The figure shows the TFI Index for European countries in 2011:

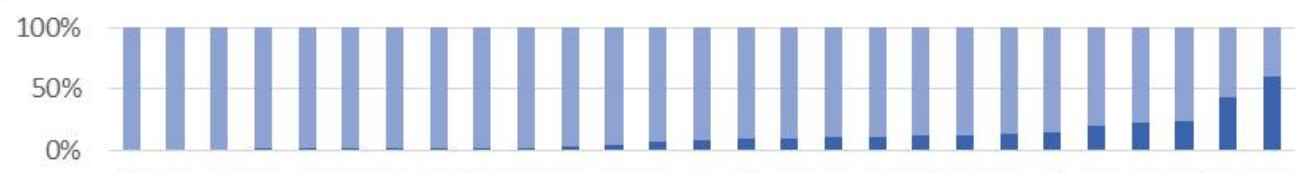

DK FI SE NL SK AT BE FR DE LU EE GB ES SI CY CZ IE LT LV PT MT GR IT PL HU RO BG

- Excluded Included

Figure 4: Total Financial Inclusion (TFI) Index

Source: Korynski, Pytkowska (2014)

Because the data used for index calculation is public, the data collecting becomes a relatively simple process. The importance of financial inclusion in reducing poverty and social exclusion is emphasized, highlighting the immediate need for Romania to implement new means of financial inclusion that could reduce the existing gap between our country and the rest of Europe.

Measuring financial exclusion requires special instruments in order to develop global, European and national policies that could lead to reducing its occurrence. International standardization bodies, especially those pertaining to the Bank for International Settlements (BIS) are actively involved in creating financial inclusion policies for more than a decade. In 2012, in Kuala Lumpur, the Malaysian workshop showed the importance of quantifying the financial exclusion in developing policies for encouraging innovation and growth in the financial services field and maintaining stability for the measures already implemented.

In the last quarter of 2015, the Irwing Fisher Committee of the Central Bank Statistics published a study about measuring financial inclusion in 47 countries: 17 well developed states and 30 with an emerging economy from Asia, Eastern Europe, and Latin America 
(including Romania). The main concerns of the study referred to the defining of financial inclusion, Central Bank policies in this field, types and sources of data used to determine index values, partnerships with global fora, and contribution to the international initiatives.

The study findings show that there is no unanimously accepted definition for financial inclusion and that Central Banks are only formally involved in financial inclusion. Data collection is superficial, and it generally refers to the number of people having a bank account or using Internet banking, but this type of data is insufficient for conclusive research. The need to harmonize quantifying and defining financial inclusion is obvious when talking about international collaboration (Irving Fisher Committee on Central Bank Statistics, 2016). G20 also shows concern and recognizes the primordial importance of financial inclusion when fighting poverty and trying to encourage sustainable development. The indicators proposed in 2012 seek to evaluate three broad perspectives: access to financial services, quality of the financial services, and usage levels. Starting with 2013, another set of indicators used to quantify the level of digital financial service usage was introduced. According to the $\mathrm{G} 20$, data collection should be carried out by public institutions so that a better level of understanding is reached. (G20, 2016)

The indicators implemented in Romania between 2011 and 2015 revealed that there is a shortage of data in this field. Relevant data shows that between 2011 and 2014 the number of people with a bank account increased from $44.6 \%$ to $60.8 \%$ (European average is $94.8 \%$ ) especially amongst individuals aged 15 to 34 (from $48.4 \%$ to $64.9 \%$ ). The number of commercial bank branches has dropped form 35.3 per 1000 adults in 2011, to 30.8 per 1000 adults in 2014. Although $91.2 \%$ of adults owned a mobile phone in 2014 , the level of debit card mobile transactions represented only $2.6 \%$ of the total. The SME loans from IFNs dropped from $93.5 \%$ in 2011 to $92.6 \%$ in 2014 . There is no indicator at this time that can measure the level of individual loans from IFNs.

Table 3: Banking account levels (\% of population aged 15 or more) between 2011-2014

\begin{tabular}{|l|c|c|}
\hline \multirow{2}{*}{} & \multicolumn{2}{|c|}{ Bank account holders } \\
\cline { 2 - 3 } & $\mathbf{2 0 1 1}$ & $\mathbf{2 0 1 4}$ \\
\hline Euro Zone & 90.6 & 94.8 \\
\hline Hungary & 72.7 & 72.3 \\
\hline Republic of Serbia & 62.2 & 83.1 \\
\hline Bulgaria & 52.8 & 63.0 \\
\hline Romania & 44.6 & 60.8 \\
\hline
\end{tabular}

Source: Barna, Vameșu (2015)

According to the report, the level of access to financial services in rural areas increased form $33.6 \%$ in 2011 to $50.4 \%$ in 2014 . The loans level is $45.7 \%$, above the European average of $35.4 \%$. Only $2 \%$ of these loans are redirected towards starting a new business or developing an already existing venture.

Table 4: Uses of loan funds in 2014 (\% of population aged 15 or more)

\begin{tabular}{|l|c|c|c|}
\hline & \multicolumn{3}{|c|}{ Type of Loans } \\
\hline Euro Zone & $\begin{array}{c}\text { Education or } \\
\text { tuition fees }\end{array}$ & $\begin{array}{c}\text { Health or other } \\
\text { medical services }\end{array}$ & $\begin{array}{c}\text { Business launch or } \\
\text { business development }\end{array}$ \\
\hline Romania & 4.0 & 3.7 & 2.8 \\
\hline Bulgaria & 5.4 & 13.3 & 2.0 \\
\hline Republic of Serbia & 2.1 & 5.0 & 1.6 \\
\hline Hungary & 2.6 & 4.1 & 2.3 \\
\hline
\end{tabular}

Source: Barna, Vameșu (2015) 
Romania has only recently started taking interest in quantifying financial inclusion. The latest study carried out by the National Romanian Bank shows that in rural areas (where $41 \%$ of the populations lives) the oldest Romanian bank - CEC Bank - owns around 900 branches, whereas other banks only have 50 branches. Out of 2686 communes in Romania, only $41 \%$ have a bank branch.

The research was conducted in 2015 in order to measure the access to financial services for working people aged between 26 and 65 with a revenue between 750 and 1700 RON. Results showed that $31.8 \%$ do not use any financial services, $60 \%$ of the people living in cities have a bank account (compared to the EU average of $90 \%$ ), $61 \%$ of the people who save money prefer to keep it at home, $37 \%$ have an outstanding loan from a bank or CAR, $2 \%$ have a loan from NBFI (Provident or Cetelem), especially people with a bad credit score.

\section{Conclusions}

Romania is far from reaching the convergence requirements imposed by the EU. Further attention should be paid to price stability, exchange rate stability, durability of convergence, and national legislation. Although the process will be demanding and challenging, better results can be achieved through structural reforms.

One of the major threats is the income inequality in our country as economic growth should be inclusive. But recent studies have confirmed an existing correspondence between levels of financial inclusion and income disparity. We believe that by increasing the level of financial inclusion the disparity can be diminished and economic growth can boost.

Data presented throughout the study shows that Romania ranked last in the financial inclusion hierarchy of European countries, while the risk of poverty or social exclusion is the highest.

We are inclined to believe that by increasing the level of financial inclusion, Romania's chances to achieve convergence will increase through the encouragement of economic growth and the reduction of income inequality and it will result in national poverty alleviation. In order for this to happen, it is strongly advised that in the future government policies are directed to the financially excluded population by developing a partnership with banks or other financial institutions.

\section{References}

Allen, F., Demirgüç-Kunt, A., Klapper, L. and Martinez Peria, M.S., 2012. The Foundations of financial Inclusion: Understanding Ownership and Use of Formal Accounts. World Bank's Policy Research Working Paper WPS6290, December.

Ampudia, M. and Ehrmann, M., 2017. Financial inclusion- what's it worth? [online] Available at: https://www.ecb.europa.eu/pub/pdf/scpwps/ecbwp1990.en.pdf, [accessed 03.09.2018]. Bayar, Y. and Gavriletea, D.M., 2018. Financial Inclusion and Economic Growth: Evidence from Transition Economies of European Union. Journal of International Finance and Economics, 18(2), pp. 95-100.

Barna, C. and Vameșu, A., 2015. Incluziune financiară prin economia socială. București: Wolters Kluwer.

Beck, T., Demirguc-Kunt, A. and Peria, M.S., 2007. Reaching out: Access to and use of banking services across countries. Journal of Financial Economics, 85 (1), pp. 234-266.

Chauvet, L. and Jacolin, L., 2017. Financial Inclusion, Bank Concentration, and Firm Performance. World Development, 97, September, pp. 1-13.

Delis, M., Hasan, I. and Kazakis, P., 2013. Bank regulations and income inequality: Empirical evidence. Review of Finance, 18 (5), pp. 1811-1846. 
Demirgüç-Kunt, A. and Klapper, L., 2013. Measuring Financial Inclusion: Explaining Variation in Use of Financial Services across and within Countries. Brookings Papers on Economic Activity, 44 (1) (Spring), pp. 279-340.

European Commission, 2018. Convergence Report. Available at: https:// ec.europa.eu/info/sites/info/files/economy- finance/ip078 en. pdf, [accessed 12.10.2018].

European Commission, 2008. Financial exclusion-Ensure an adequate access to basic financial services, European Commission, Report type - Memo G20, 2016. Financial Inclusion Indicators, Available at: https://www.gpfi.org/sites/default/files/documents/ G20\%20Financial\%20Inclusion\%20Indicators\%20\%282016\%20Update\%29.pdf,[accessed 06.03.2017].

Irving Fisher Committee on Central Bank Statistics, 2016. Measures of financial inclusion - a central bank perspective. IFC Report. Bank for International Settlements.

Kim, D.W., Yu, J.S. and Hassan, M.K., 2018. Financial inclusion and economic growth in OIC countries. Research in International Business and Finance, 43, pp. 1-14.

Klapper, L., Lusardi, A. and van Oudheusden, P., 2015. Financial Literacy Around the World: Insight from the Standard and Poor's Ratings Services Global Financial Literacy Survey [online], Available at: http://media.mhfi.com/documents/2015-Finlit_paper_17_F3 _ SINGLES.pdf, [accessed 08.2016].

Korynski, P. and Pytkowska, J., 2014. Measuring Financial Inclusion in the EU: The New "Financial Inclusion Score". European Commission, Report type- Policy Paper.

Naceur, S.B. and Samir, G., 2007. Stock markets, banks, and economic growth: empirical evidence from the MENA region. Research in International Business and Finance, 21 (2), pp. 297-315.

Pradhan, R.P., Arvin, B.M., Norman, N.R., Nair, M. and Hall, J.H., 2016. Insurance penetration and economic growth nexus: cross-country evidence from ASEAN. Research in International Business and Finance, 36, pp. 447-458.

Réseau Financement Alternatif, 2008. Financial Services Provision and Prevention of Financial Exclusion. European Commission, Directorate-General for Employment, Social Affairs and Equal Opportunities, Inclusion, Social Policy Aspects of Migration, Streamlining of Social Policies.

\section{Bionote}

Oana Cojocaru and Otilia Floroiu are both $\mathrm{PhD}$ students in fourth year of study at Stefan cel Mare University of Suceava. Oana Cojocaru is working on her PhD thesis: "Microfinance Development Strategies Specific to the present Regional Development Processes" and Otilia Floroiu is working on her PhD thesis: "Efficient Strategies for the Euro Currency Adoption in Romania". 